
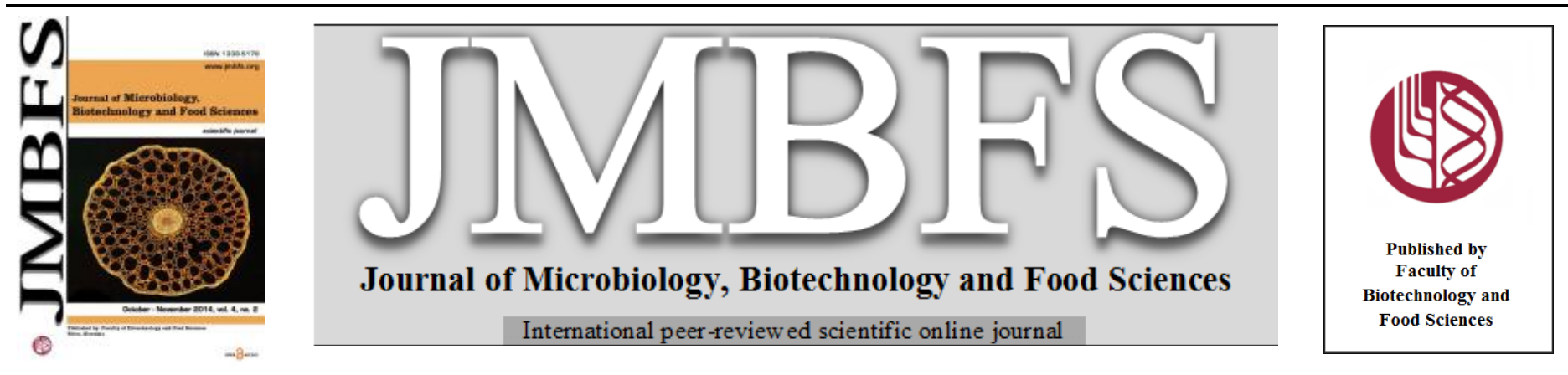

\title{
ENHANCED DEGRADATION OF CAPTAN BY IMMOBILIZED CELLS OF BACILLUS CIRCULANS
}

\author{
Address(es): \\ ${ }^{1}$ Department of Biochemistry, MSRCASC, Mattikere, MSRIT Post, Bangalore-560054. \\ ${ }^{2}$ Department of Chemistry, Government Arts \& Science College, Karwar-581301. \\ ${ }^{3}$ Department of Biochemistry, CPGS, Jain University, Bangalore-560011. \\ ${ }^{4}$ Department of Biology-Chemistry, CE, University of Rwanda, Kigali-5039. \\ ${ }^{5}$ Department of Biochemistry, Karnataka University, Dharwad-58003.
}

Veena More ${ }^{1}$, Preeti Tallur ${ }^{2}$, Sunil S. More ${ }^{3}$, Francois N. Niyonzima ${ }^{4}$, and Harichandra Ninnekar ${ }^{5}$

*Corresponding author: sunilacr@yahoo.co.in

doi: 10.15414/jmbfs.2014.4.2.108-111

\section{ARTICLE INFO}

Received 11. 7. 2014

Revised 29. 7. 2014

Accepted 20. 8. 2014

Published 1. 10. 2014

Regular article

open $\mathcal{O}_{\text {ACCESS }}$

\begin{abstract}
The possibility of using Bacillus circulans in degrading captan was evaluated by comparing the captan degradation rate by freely suspended and immobilized cells on agar, sodium alginate (SA), polyacrylamide (PA) and polyurethane-foam (PUF) in batch and repeated batch degradations. Under batch degradations, $50,60,72$, and $88 \%$ of $0.1 \%$ captan was degraded by freely suspended cells, agar-, SA-, and PA-immobilized cells, respectively in $72 \mathrm{~h}$; whereas $15,47.5,67.7$ and $75 \%$ of $0.2 \%$ captan was degraded by freely suspended cells, agar-, SA-, and PA-immobilized cells, respectively in $72 \mathrm{~h}$. However, 0.1 and $0.2 \%$ captan were completely degraded by PUF-immobilized cells in 48 and $72 \mathrm{~h}$, respectively. Under repeated batch degradations, PUF-immobilized cells were reused more than 40 cycles for $72 \mathrm{~h}$ without losing the captan degradation ability, while the cells immobilized on agar, SA, and the PA could be reused for 15, 20, and 25 cycles, respectively. A significant $0.1 \%$ captan degradation by PUF-immobilized cells was observed at $\mathrm{pH} 4.0$ - 10.0 and $20-40{ }^{\circ} \mathrm{C}$ ranges. In contrast, freely suspended cells only degraded captan at optimum pH of 7.0 and $30{ }^{\circ} \mathrm{C}$. The PUFimmobilized cells were able to significantly degrade captan for 120 days at $4{ }^{\circ} \mathrm{C}$ without losing the captan degradation ability; whereas this ability was lost in 120 days for freely suspended cells. Since the application of captan leads to pollution and reduces soil fertility, the use of immobilized cells of Bacillus circulans can thus be a better cost-effective strategy to decontaminate captan polluted sites.
\end{abstract}

Keywords: Polyurethane-foam, polyacrylamide, biodegradation, Bacillus circulans, captan

\section{INTRODUCTION}

Microorganisms play a critical role in the degradation of toxic compounds (Ye $\boldsymbol{e t}$ al., 2004). The degradation of these compounds by fungal or bacterial immobilized cells has not been fully exploited (Megadi et al., 2010). The microbial cells associated with or entrapped within an insoluble matrix are known as immobilized cells. Adsorption, entrapment within a semipermeable membrane or in three dimensional polymer network, covalent coupling, and confinement in a liquid emulsion are some of the methods used for microbial cells immobilization (Jonathan, 1988). The removal of the environmental organic pollutants by microorganisms was considered as a better safe and inexpensive strategy (Megadi et al., 2010) since the inert matrices used for immobilization of microbial cells are cheap and non-toxic to bacteria or fungi (Zheng et al., 2009). The immobilized bacterial or fungal cells have various advantages over freely suspended cells under numerous conditions. For instance, utilization of immobilized cells allows the bioreactors to function at flow rates independent of the microbial growth rates, resist higher concentrations of toxic substrates, and once the cells are immobilized, they can be re-used continuously (Bettmann and Rehm, 1984; Hall et al., 1991; Cassidy et al., 1996; Zheng et al., 2009).

Fungicides, rodenticides, insecticides, bactericides, acasicides, herbicides, and nematicides constitute the 7common types of pesticide (Al hattab and Ghaly, 2012). The captan (N-trichloromethylthio-4-cyclohexene-1,2-dicarboximide), like other phthalimide fungicides such as folpet and captafol, is utilized to combat the agricultural plant diseases caused by various fungal species (Schwack and Flober-Muller, 1990). It is also used to inhibit the fungal growth on various industrial products such as textiles, plasters and plastics (Rawn et al. 2008). Captan is also known to be mutagenic and carcinogenic to human beings, to poison some animals (Shirasu et al., 1976) and to cause soil infertility by killing soil microorganisms necessary for nitrogen fixation, phosphate and other nutrients absorption (Banerjee and Banerjee, 1987; Martinez-Toledo et al. 1998). The toxicity of captan was attributed to the $-\mathrm{SCCl}_{3}$ group which reacts intracellularly to form thiophosgene that may undergo reaction with some free functional groups like $-\mathrm{SH}$ and $-\mathrm{NH}_{2}$, to prevent important metabolic pathways
(Wolfe et al., 1976; Buyanovsky et al., 1988; Cassidy et al., 1996). An inexpensive proper strategy to degrade the captan is thus required.

Few reports are available for the degradation of captan by freely suspended cells of soil microorganisms (Buyanovsky et al., 1988) and Bacillus circulans (Megadi et al., 2010). However, there is no report for captan degradation by immobilized bacterial or fungal cells. We have previously reported the complete mineralization of captan by Bacillus circulans into a series of steps, involving hydrolysis of captan to cis-1,2,3,6-tetrahydrophthalimide, and the oxidation of the later to o-phthalic acid through cis 1,2,3,6- tetrahydrophthalimidic acid, conversion of o-phthalic acid to protocatechuic acid, and ortho cleavage of the latter to 3-carboxy-cis,cis muconic acid (Megadi et al., 2010). In the present investigation, captan was subjected to degradation by freely suspended and immobilized Bacillus circulans cells on agar, sodium alginate, polyacrylamide, and PUF inert materials.

\section{MATERIALS AND METHODS}

Chemicals and reagents

Captan was agenerous gift from Rallis Agrochemicals India Ltd. (Mumbai, India). Polyurethane foam was procured from local market, whereas acrylamide, bisacrylamide, ammonium persulphate, sodium alginate, nutrient agar, and agaragar were purchased from HiMedia Laboratories (Mumbai, India). The other chemicals and reagents were of analytical grade.

\section{Microorganism and culture media}

The Bacillus circulans used in the present study was isolated from soil by enrichment culture technique and was found to use fungicide captan (Megadi $\boldsymbol{e t}$ al., 2010) as a sole source of carbon source. Mineral agar slant coated with captan was used to maintain the Bacillus circulans culture (Megadi et al., 2010) Mineral salt media (MM1 and MM2) were utilized. The composition of MM1 used to pre-cultivate the bacterium was (w/v) $0.63 \% \mathrm{~K}_{2} \mathrm{HPO}_{4}, 0.183 \% \mathrm{KH}_{2} \mathrm{PO}_{4}$, $0.1 \% \mathrm{NH}_{4} \mathrm{NO}_{3}, 0.01 \% \mathrm{MgSO}_{4} .7 \mathrm{H}_{2} \mathrm{O}, 0.01 \% \mathrm{CaCl}_{2} .2 \mathrm{H}_{2} \mathrm{O}, 0.01 \% \mathrm{FeSO}_{4} .7 \mathrm{H}_{2} \mathrm{O}$, 
$0.0005 \% \mathrm{Na}_{2} \mathrm{MoO}_{4} \cdot 2 \mathrm{H}_{2} \mathrm{O}$, and $0.01 \% \mathrm{MnSO}_{4} \cdot \mathrm{H}_{2} \mathrm{O}$. The medium was boiled, filtered and the $\mathrm{pH}$ was adjusted to 7.0. The medium was then dispersed in 100 $\mathrm{ml}$ quantities in $500 \mathrm{ml}$ Erlenmeyer flasks and sterilized by autoclaving. The MM2 was used for the degradation studies, and contained the following constituents (w/v): $0.63 \% \mathrm{~K}_{2} \mathrm{HPO}_{4}, 0.1 \% \mathrm{NH}_{4} \mathrm{NO}_{3}, 0.02 \% \mathrm{MgSO}_{4} .7 \mathrm{H}_{2} \mathrm{O}, 0.002 \%$ $\mathrm{CaCl}_{2} .2 \mathrm{H}_{2} \mathrm{O}$, and $0.005 \% \mathrm{FeCl}_{3}$. The medium was boiled, filtered and the $\mathrm{pH}$ was adjusted to 7.0. The medium was then dispersed in $100 \mathrm{ml}$ quantities in $500 \mathrm{ml}$ Erlenmeyer flasks and sterilized by autoclaving for $15 \mathrm{~min}$ at $15 \mathrm{psi}$. After MM1 sterilizationand before bacterial inoculation, 0.1 or $0.2 \%$ captan sterilized by membrane filtration was added.

\section{Immobilization of Bacillus circulans cells in various matrices}

MM1 supplemented with captan was utilized to grow Bacillus circulans. A centrifugation at $5000 \mathrm{x} \mathrm{g}$ for $10 \mathrm{~min}$ at $15{ }^{\circ} \mathrm{C}$ was used to collect bacterial cells when the culture reached mid-logarithmic growth phase. A phosphate buffer $(\mathrm{pH}$ 7.0) of $50 \mathrm{mM}$ strength was used to wash the bacterial cells. The cells were then immobilized in different matrices namely alginate (Bettmann and Rehm, 1984), agar (Jonathan, 1988), cross-linked and pre-polymerized linear polyacrylamides (Jonathan, 1988), and polyurethane foam (PUF) (Hall et al. 1991).

\section{Batch degradation of captan by bacterial cells}

The captan was degraded under batch conditions using freely suspended and immobilized bacterial cells in different matrices with a suitable control. For freely suspended bacterial cells, $97.5 \mathrm{ml}$ of MM2 in 500-ml conical flasks containing 0.1 or $2 \%$ captan was inoculated with $2.5 \mathrm{ml}$ of freely exponentially growing bacterial cells, and incubated on a rotary shaker $(150 \mathrm{rpm})$ at $30^{\circ} \mathrm{C}$. For immobilized cells, $97.5 \mathrm{ml}$ of MM2 in 500-ml conical flasks containing 0.1 or $0.2 \%$ captan was taken and $10 \mathrm{~g}$ of wet beads/foam cubes of each inert material (containing around 1.0 to $1.1 \times 10^{10} \mathrm{cfu} / \mathrm{g}$ beads or foam cubes) was added. The incubation was carried out in the same conditions as for free suspended cells.Heat killed bacterial cells were used as control. The residual captan from spent medium was analyzed at regular intervals by Reverse-Phase High Performance Liquid Chromatography (RP-HPLC).

\section{Repeated batch degradation of captan by bacterial cells}

The repetitive batch degradations were performed in order to evaluate the longevity of degrading activity of immobilized cells in various matrices Following every cycle of incubation period ( $96 \mathrm{~h} /$ cycle), a decantation was carried out for spent medium and distilled water was used to wash the obtained beads/foam cubes. After washing, the cubes were then placed in a freshly prepared MM2 medium supplemented with captan, and incubated under similar degradation conditions. The spent medium was utilized for the residual captan quantification by HPLC.

Effect of pH and temperature on captan degradation by freely suspended and PUF-immobilized cells

The rate of degradation of captan by freely suspended cells and PUFimmobilized cells of Bacillus circulans at different $\mathrm{pH}$ (3.5-10.5) and temperature $\left(20-50{ }^{\circ} \mathrm{C}\right)$ was quantified after $96 \mathrm{~h}$ of incubation.

\section{Storage stability of freely suspended and PUF-immobilized bacterial cells in degrading captan}

The storage stability of both free suspended and PUF-immobilized cells was recorded every 10 days at $4{ }^{\circ} \mathrm{C}$ for a period 120 days.

\section{Analytical methods}

The captan in the spent medium was recorded by RP- HPLC equipped with UV detector using Spherisorb-ODS, $\mathrm{C}_{18}$ column, $25 \mathrm{~cm}$ x $4.6 \mathrm{~mm}, 5 \mu \mathrm{m}$ (Shimadzu, Japan). A mixture of acetonitrile (mobile phase A) and $0.05 \mathrm{M}$ phosphate buffer of $\mathrm{pH} 7.0$ (mobile phase B) (70:30, v/v) served as the mobile phase at a flow rate of $1 \mathrm{ml} / \mathrm{min}$. Scanning was carried out in the 220 to $400 \mathrm{~nm}$ range and the peaks were detected at $254 \mathrm{~nm}$.

\section{Statistical Analysis}

All the experiments to quantify the captan in the spent medium were done in triplicate. With SPSS statistical package (PASW Statistics 18), the significant differences between the means, at the level of significance of 5\%, were given by one way analysis of variance (ANOVA) followed by Duncan's multiple range test (DMRT).

\section{RESULTS}

Degradation of captan by freely suspended and immobilized cells of Bacillus circulans in batch cultures

A soil isolate capable of using very efficiently phthalimide fungicide captan as carbon source was used in the present study. The free cells of Bacillus circulan were able to degrade $50 \%$ of $0.1 \%$ w/v captan in $72 \mathrm{~h}$ (Fig 1). In contrast, cells immobilized in agar, SA and polyacrylamide degraded 60,72 and $88 \%$ of the $1 \%$ captan, respectively for a period of $72 \mathrm{~h}$. However, a complete $0.1 \%$ captan degradation was observed for bacterial cells immobilized on PUF in $48 \mathrm{~h}$ (Fig 1). $\mathrm{A}$ at a concentration of $0.2 \% \mathrm{w} / \mathrm{v}$, freely suspended cells only degraded $15 \%$, while the cells immobilized on agar, SA, polyacrylamide, and PUF degraded $47.5,67.5,75$, and $100 \% \mathrm{w} / \mathrm{v}$, respectively for a period of $72 \mathrm{~h}$ (Fig 2). When the initial concentration of captan was increased to $0.5 \% \mathrm{w} / \mathrm{v}$, the rate of degradation by cells immobilized in agar, alginate and polyacrylamide decreased significantly, but the cells immobilized in polyurethane foam (PUF) completely degraded $0.5 \% \mathrm{w} / \mathrm{v}$ captan in $96 \mathrm{~h}$ and $0.9 \%$ captan for a period of $120 \mathrm{~h}$ (data not shown).

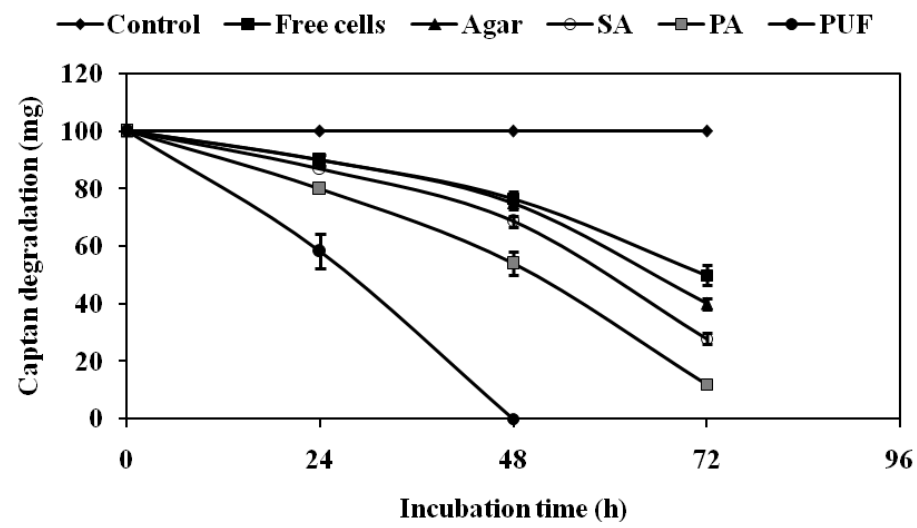

Figure 1 Batch culture degradation of $0.1 \%$ captan by cells of Bacillus circulans immobilized on polyurethane-foam (PUF, -•-), polyacrylamide (PA, - - -), sodium alginate (SA, - - -), agar (- $\mathbf{-}-)$, and by free suspended cells (- - -). The uninoculated culture acted as control (- $\bullet$ -

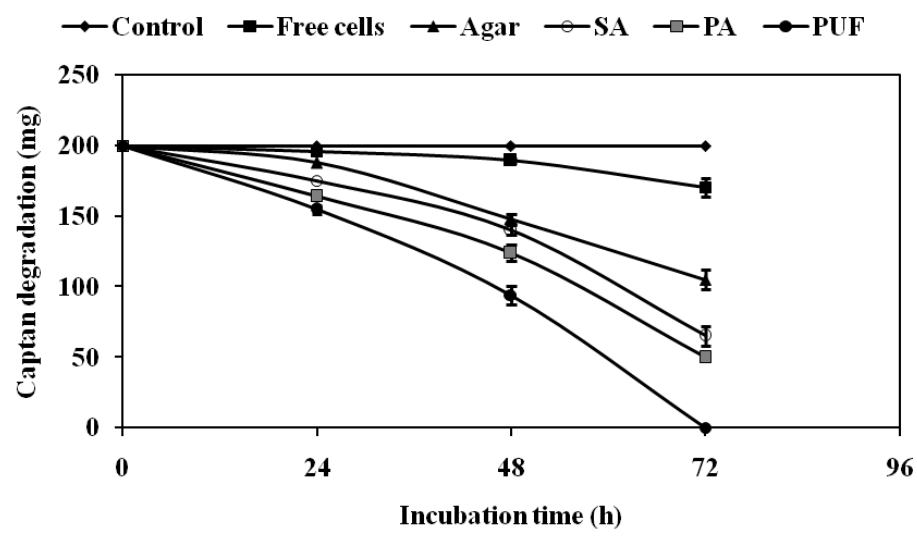

Figure 2 Batch culture degradation of $0.2 \%$ captan by cells of Bacillus circulans immobilized on polyurethane-foam (PUF, - $\bullet-$ ), polyacrylamide (PA, - - - ), sodium alginate (SA, - - -), agar (- $\boldsymbol{\Delta}-)$, and by free suspended cells $(-\boldsymbol{-}-)$. The uninoculated culture acted as control $(-\bullet-)$.

Semi-continuous degradation of captan by immobilized Bacillus circulans cells

The cells immobilized in different inert materials were semi-continuously used for degradation of $0.1 / 0.2 \%$ captan. It was noticed that for an initial captan concentration of 0.1 or $2 \%$, the agar, SA, polyacrylamide and PUF-immobilized bacterial cells could be reused for 15, 20, 25, and 40 cycles respectively, without losing captan degradation ability. Polyurethane-foam immobilized cells can be reused more than 40 cycles for a period of $72 \mathrm{~h}$ without losing the capacity to degrade captan (Fig 3 and 4). However, when initial amount of captan was increased to $0.5 \%$ the immobilized cells in agar, alginate and polyacrylamide could also be reused but with a significant decreased captan degradation rate; however, PUF-immobilized cells was reused about 30 cycles without decrease of the captan degradation rate (data not shown). 


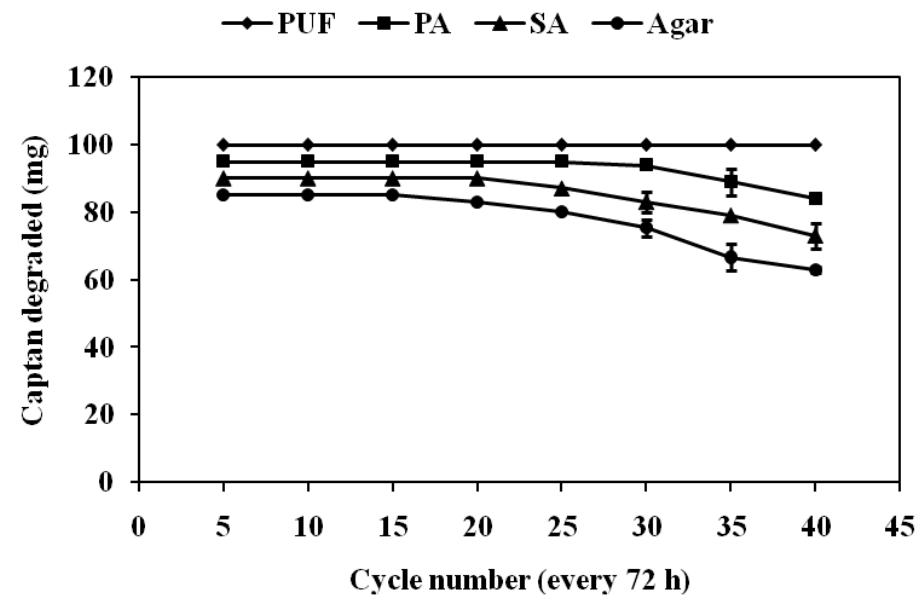

Figure 3 Semi-continuous degradation of captan $(0.1 \%)$ by cells of Bacillus circulans immobilized on polyurethane-foam (PUF, - -), polyacrylamide (PA, --), sodium alginate (SA, - $\mathbf{\Lambda}-$ ), and agar (-๑)

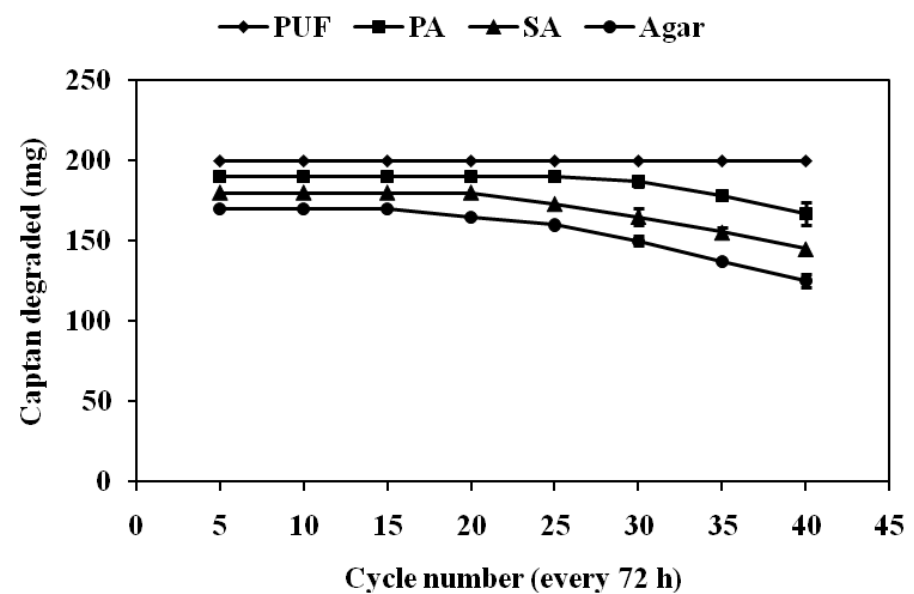

Figure 4 Semi-continuous degradation of captan $(0.2 \%)$ by cells of Bacillus circulans immobilized on polyurethane-foam (PUF, - -), polyacrylamide (PA, -

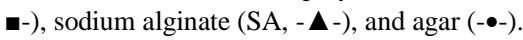

Effect of $\mathrm{pH}$ on captan degradation rate by PUF-immobilized bacterial cells

The influence of $\mathrm{pH}$ on captan degradation by freely suspended and PUFimmobilized bacterial cells was analyzed as shown in the Fig 5. The PUFimmobilized cells completely degraded captan in all the temperatures investigated, except at $\mathrm{pH} 4.0$ and 10.0 where only about $10 \%$ was not degraded. However, complete captan degradation by freely suspended cells was only observed at $\mathrm{pH} 7.0$, whereas for other $\mathrm{pH}$ values a decrease in degradation rate was important as there is a deviation from optimum $\mathrm{pH}$.

\section{口Freely suspended cells 口PUF-immobilized cells}

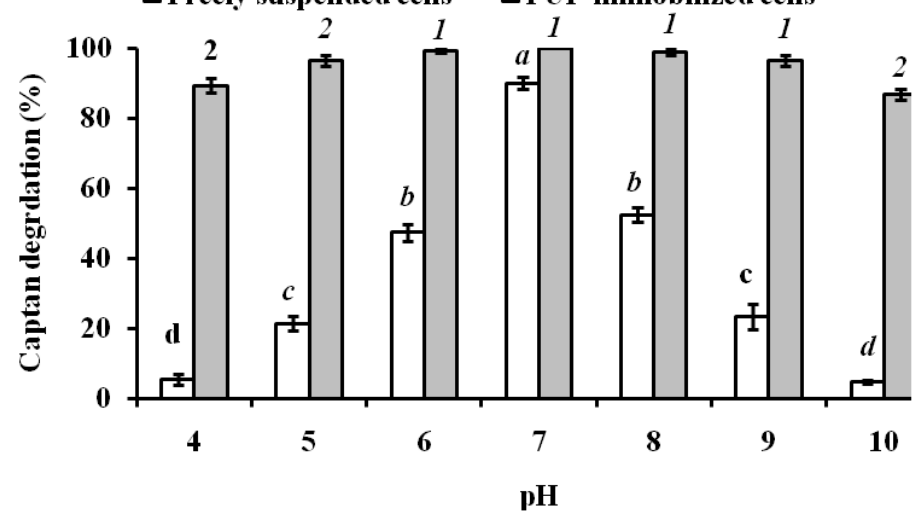

Figure 5 Effect of $\mathrm{pH}$ on $0.1 \%$ captan degradation by freely suspended (- - -) and PUF-immobilized (-m-) Bacillus circulans cells. The captan degradation values with different numbers or alphabets on the error bars significantly differ from each other at $\mathrm{P}_{0.05}$
Effect of temperature on captan degradation rate by PUF-immobilized bacterial cells

The effect of temperature on captan degradation by PUF-immobilized cells was evaluated and the immobilized cells degraded the fungicide at all the temperatures investigated in the 20 to $40^{\circ} \mathrm{C}$ range, but a slight decrease in captan degradation was seen only at $45{ }^{\circ} \mathrm{C}$. The freely suspended bacterial cells were only active at $30{ }^{\circ} \mathrm{C}$ and a partial reduction of about $50 \%$ in captan degradation of was seen for other studied temperatures (Fig 6).

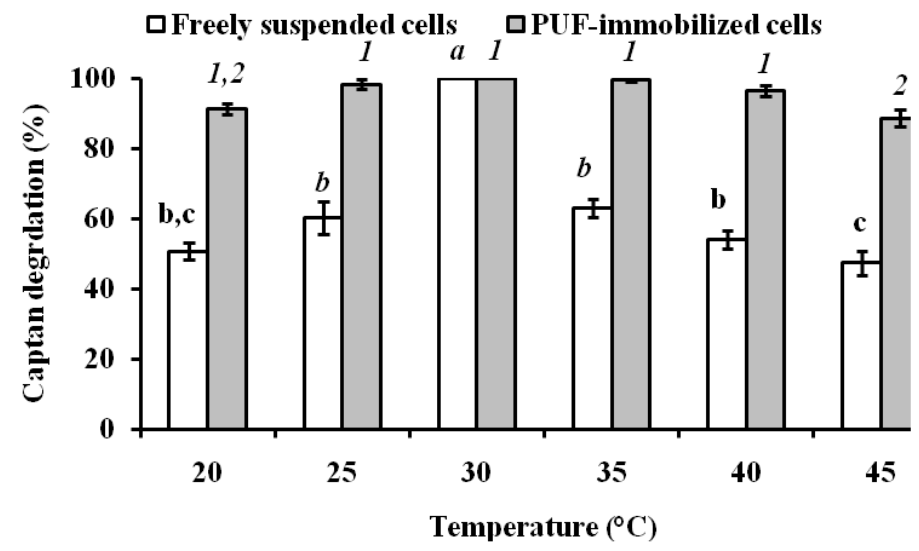

Figure 6 Influence of temperature on the captan degradation by freely suspended cells (-ם-) and PUF-immobilized Bacillus circulans cells (-m-). The captan degradation values with different numbers or alphabets on the error bars significantly differ from each other at $\mathrm{P}_{0.05}$

\section{Storage stability of the PUF-immobilized cells degrading captan}

The PUF-immobilized cells were able to degrade captan for 70 days at $4{ }^{\circ} \mathrm{C}$ without losing the captan degradation ability, and a loss of $11 \%$ in captan degradation was seen after 4 months. However, the freely suspended cells showed a gradual decrease in capacity of captan degradation and after 120 days, the free cells were completely lost the captan degrading ability (Fig 7).

\section{$\rightarrow \sim$ Freely suspended cells $\rightarrow$ PUF-immobilized cells}

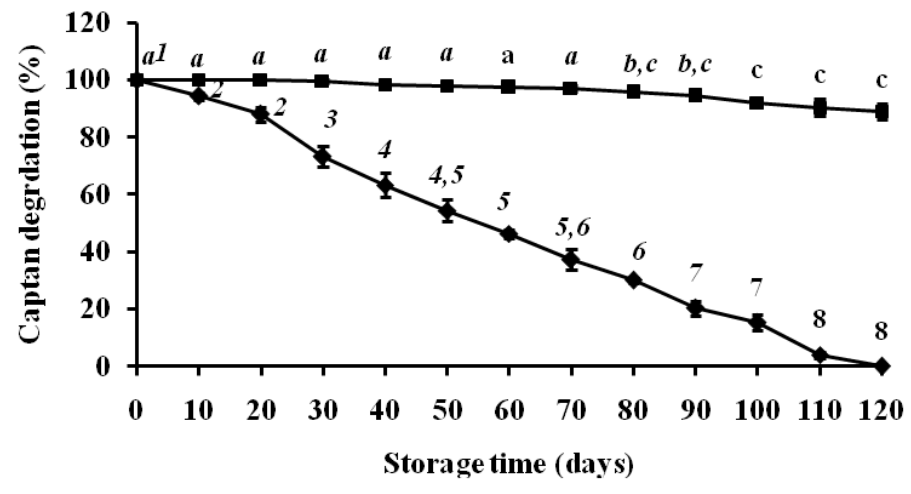

Figure 7 Storage stability of freely suspended (- - ) and PUF-immobilized (- $\mathbf{-}$-) Bacillus circulans cells grown on $0.1 \%$ captan. The captan degradation values with different numbers or alphabets on the error bars significantly differ from each other at $\mathrm{P}_{0.05}$

\section{DISCUSSION}

The present investigation focused on the captan degradation by Bacillus circulan screened from soil by freely suspended and immobilized bacterial cells on agar, SA, PA, and PUF. In batch cultures, the captan degradation by immobilized cells on various matrices increased at higher concentration than compared to freely suspended cells.Captan at aconcentration of $0.3 \% \mathrm{w} / \mathrm{v}$ was not degraded by free cells and 50\% of the inoculated microorganism was killed because of captan toxicity. The PUF-immobilized cells degraded captan up to the concentration of $0.9 \%(\mathrm{w} / \mathrm{v})$. The increased degradation of toxic compounds by immobilized cells was attributable to higher population of cells in these inert materials. The immobilized cells also get protected from high substrate concentration toxicity (Hall et al. 1991; Cassidy et al., 1996).

The semi-continuous degradation results revealed that at higher captan concentration, cells immobilized in agar, SA, and PA showed a slight decreased rate of degradation of captan with increased cycle number.However, PUFimmobilized bacterial cells maintained the captan degrading ability and was reused more than 40 cycles without losing the captan degradation ability. This 
was ascribed to high porosity, adsorbing capacity and stability as well as high mechanical strengths of the PUF-immobilized cells compared to agar, SA and PA matrices (Trevors et al., 1993; Zheng et al., 2009).Compared to PUFimmobilized cells, low degradation ability observed for cells immobilized in agar, SA, and polyacrylamide was ascribed to gradual cell leakage and mechanical instability by Trevors et al. (1993). The PUF-immobolized Bacillus circulans cells were active for 4 months in the 20 to $40{ }^{\circ} \mathrm{C}$ range over a broad pH range of 6.0 to 9.0 , suggesting captan degradation under various environmental conditions. The degradation of toxic fungicides can thus be achieved using immobilized microbial technology.

\section{CONCLUSION}

A Bacillus circulans capable of degrading captan was immobilized in agar, SA, PA and polyurethane foam. An effective degradation of captan was observed with PUF-immobilized bacterial cells rather than the other inert materials tested or freely suspended cells. Since the application of phthalimide fungicides leads to the pollution and reduce soil fertility, the use of immobilized cells of Bacillus circulans can be an ideal choice to degrade these environmental toxic pollutants.

\section{REFERENCES}

AL HATTAB, M.T., GHALY, A.E. 2012. Sequential remediation processes for a low level pesticide wastewater. Journal of Environmental Protection, 3, 150 163. http://dx.doi.org/10.4236/jep.2012.32019

BANERJEE, A., BANERJEE, A.K. 1987. Influence of captan on some microorganisms and microbial processes related to the nitrogen cycle. Plant Soil, 102, 239-245. http://dx.doi.org/10.1007/BF02370709

BETTMANN, H., REHM, H.J. 1984. Degradation of phenol by polymer entrapped microorganisms. Applied Microbiology and Biotechnology, 20, 285290. http://dx.doi.org/10.1007/BF00270587

BUYANOVSKY, G.A., PIECZONKA, G.J., WAGNER, G.H., FAIRCHILD,

M.L. 1988. Degradation of captan under laboratory conditions. Bulletin of Environmental Contamination and Toxicology, 40, 689-695. http://dx.doi.org/10.1007/BF01697516

CASSIDY, M.B., LEE, H., TREVORS, J.T. 1996. Environmental applications of immobilized microbial cells: a review. Journal of Industrial Microbiology, 16, 79-101. http://dx.doi.org/10.1007/BF01570068

HALL, D.O., RAO, K.K., PARK, I.H. 1991. Immobilized photosynthetic membranes and cells for the production of fuels and chemicals. Studies of Environmental Science, 42, 259-275. http://dx.doi.org/10.1016/S01661116(08)70332-7

JONATHAN, W. 1988. Methods of immobilization of microbial cells. Journal of Microbiological Methods, 8, 91-102. http://dx.doi.org/10.1016/01677012(88)90041-3

MARTINEZ-TOLEDO M.V., SALMERON, V., RODELAS, B., POZO, C., GONZALEZ-LOPEZ, J. 1998. Effects of fungicide captan on some functional groups of soil microflora. Applied Soil Ecology, 7, 245-255. http://dx.doi.org/10.1016/S0929-1393(97)00026-7

MEGADI, V.B., TALLUR, P.N., MULLA, S.I., NINNEKAR, H.Z. 2010.

Bacterial degradation of fungicide captan. Journal of Agricultural and Food Chemistry, 58, 12863-12868. http://dx.doi.org/10.1021/jf1030339

RAWAN, D.F.K., QUADE, S.C., SUN, W.F., FOUGUET, A., BELANGER, A. SMITH, M. 2008. Captan residue reduction in apples as a result of rinsing and $\begin{array}{lll}\text { peeling. } \quad \text { Food } & \text { 790-796 }\end{array}$ http://dx.doi.org/10.1016/j.foodchem.2008.01.061

SCHWACK, W., FLOBER-MULLER, H. 1990. Fungicides and photochemistry. Photodehalogenation of captan .Chemosphere, 21, 905-912. http://dx.doi.org/10.1016/0045-6535(90)90170-X

SHIRASU, Y., MORIYA, M., KATO, K., FURUHASHI, A., KADA, T. 1976.

Mutagenicity screening of pesticides in the microbial system. Mutation Research, 40, 19-30. http://dx.doi.org/10.1016/0165-1218(76)90018-5

TREVORS, J.T., VAN ELSAS J.D., LEE, H., WOLTERS, A.C. 1993. Survival of alginate-encapsulated Pseudomonas fluorescens cells in soil. Applied Microbiology and Biotechnology, 39, 637-643. http://dx.doi.org/10.1007/BF00205067

YE, J., SINGH, A., WARD, O.P. 2004. Biodegradation of nitroaromatics compounds and other nitrogen-containing xenobiotics. World Journal of Microbiology and Biotechnology, 20, 117-135. http://dx.doi.org/10.1023/B:WIBI.0000021720.03712.12

WOLFE, N.L., ZEPP, R.G., DOSTER, J.C., HOLLIS, R.C. 1976. Captan hydrolysis. Journal of Agricultural and Food Chemistry, 24, 1041-1045. http://dx.doi.org/10.1021/jf60207a004

ZHENG, C., ZHOU, J., WANG, J., QU, B., WANG, J., LU, H., ZHAO, H. 2009 Aerobic degradation of nitrobenzene by immobilization of Rhodotorula mucilaginosa in polyurethane foam. Journal of Hazardous Materials, 168, 298 303. http://dx.doi.org/10.1016/j.jhazmat.2009.02.029 